Article

\title{
My Brother the "Other": Use of Satire and Boundary-Making by Venezuelan Migrants in Peru
}

\author{
Leda M. Pérez * and Luisa Feline Freier \\ Department of Social and Political Sciences, Universidad del Pacífico, Peru \\ * Corresponding author (I.perez@up.edu.pe)
}

Submitted: 15 August 2021 | Accepted: 21 October 2021 | Published: 25 January 2022

\begin{abstract}
While the criminalization and hyper-sexualization of Venezuelan migrants and refugees across South America have received growing scholarly attention, fairly little is known about the coping strategies of migrants in this context. In this article, we build on quantitative and qualitative data from a survey $(\mathrm{N}=100), 72$ in-depth interviews, and five focus groups with Venezuelan immigrants in five Peruvian cities, collected between 2018 and 2020, to explore how they make sense of, and react to, negative shifts in public opinion on immigration and the criminalization of Venezuelan nationals. We identify two broad coping mechanisms: (a) opposition to their criminalization, including its satirical ridiculing, and (b) intra-group boundary-making and "othering." Our findings make an important contribution to the literature on migrant responses to criminalization and intra-group relations in the Global South.
\end{abstract}

\section{Keywords}

coping; discrimination; intra-group othering; satire; South-South migration; Venezuelan displacement

\section{Issue}

This article is part of the issue "Recent Trends in Inequality and Exclusion in Latin America" edited by Maria Amparo Cruz Saco (Connecticut College / Universidad del Pacífico).

(C) 2022 by the author(s); licensee Cogitatio (Lisbon, Portugal). This article is licensed under a Creative Commons Attribution 4.0 International License (CC BY).

\section{Introduction}

In the past five years, scholars have characterized Venezuelan displacement as a "migration of despair" (Paez \& Vivas, 2017), in response to the country's deepening economic, political, and humanitarian crisis, which has been stoked by falling international petroleum prices and opposition to President Nicolás Maduro's governance. As of October 2021, over 5.9 million Venezuelans have fled their homes due to generalized violence, poverty, and lack of access to health and education, among other reasons (R4V, 2021), rendering it the second-largest and fastest-growing displacement scenario worldwide (Freier \& Parent, 2019). The nature of this displacement is largely regional, with over 4.8 million living in Latin America and the Caribbean (R4V, 2021).

A growing body of literature on Venezuelan displacement across Latin America has documented integration processes in receiving countries (Aliaga et al., 2020;
Freier \& Pérez, 2021; Pérez \& Ugarte, 2021). In recent years, a topic of increasing interest has been the criminalization of Venezuelans across the region (Blouin, 2019; Concha, 2018; Freier \& Parent, 2019; Freier \& Pérez, 2021; García, 2020; Pérez \& Freier, 2021). In Peru more specifically, studies tend to examine Venezuelan men and women's criminalization experiences in both the public sphere and in the workplace (Freier \& Pérez, 2021), as well as the interconnectedness between Venezuelan women's hyper-sexualization and criminalization (Pérez \& Freier, 2021; Pérez \& Ugarte, 2021). While this migration is still unfolding, and notwithstanding the research conducted, we know relatively little about the reactions and coping strategies of migrants in this context.

Contributing to the study of how Venezuelans make sense of, and react to, negative shifts in public opinion on immigration and their criminalization in everyday life, this article first asks how these migrants in Peru approach their criminalization. Here, we explore 
respondents' reactions to damaging changes in public opinion regarding how they are positioned in Peruvian society as delinquents and/or undesirable subjects. We find two broad types of reactions: (a) satirical opposition and (b) intra-group boundary-making. In light of these responses, a second question that arises is: Are there specific socioeconomic and political conditions in Peru that have hastened such coping mechanisms?

Overall, we argue that Venezuelan migrants' use of satire and intra-group boundary-making developed as a response to changing policy and political conditions in the host country, which increased overall instances of discrimination and criminalization and created barriers for their socio-economic integration-particularly their access to gainful employment. As "migrants of despair," the main reason for choosing Peru as a destination was linked to the country's early policy that granted them temporary work permits (Aron \& Castillo Jara, 2020; Freier \& Castillo Jara, 2020). However, this reality was short-lived. Our research shows that Venezuelans who arrived before June 2019-when the policy changed-sought to underscore their value, on the one hand, while differentiating themselves from later-arriving compatriots, on the other. Our findings demonstrate that, for Venezuelan migrants in Peru, specific coping mechanisms surfaced as a response to their socioeconomic precarity in an increasingly hostile climate. This case study contributes to the literature on migrant responses to criminalization and intra-group relations in the Global South.

The remainder of this article is structured as follows: The second section provides a review of the literature on migrant criminalization and intra-group boundary-making. We follow this with a brief overview of Venezuelan emigration to Peru and its increasing criminalization. The fourth section describes our methods. We then present our findings, followed by a discussion of our data. The final section concludes with some suggestions for further research on this subject.

\section{Migrant Criminalization and Intra-Group Boundary-Making}

Two strands of literature serve as a prism for our analysis. The first, on migrant criminalization, includes research primarily from the Global North, as well as some incipient scholarship from the Global South. The second, on migrants' use of satire and intra-group boundary-making as coping mechanisms, is comparatively less developed overall and nearly inexistent in the Global South.

\subsection{The Criminalization of Migration}

Historically, the literature devoted to immigrant criminalization has focused on south-north or east-west migration (Armenta, 2016, 2017; Escobar, 2016; Korteweg, 2017), where analyses have contributed to both theoretical and empirical understandings relative to judicial and legal processes and national security (Abrego et al., 2017; Armenta, 2016; McDowell \& Wonders, 2010), as well as to immigrants' integration experiences (Korteweg, 2017; Van Klingeren et al., 2015). As immigrants are positioned as social threats and/or criminalized, this construction might occur through both migration status and/or race, depending on their country of origin (Brown et al., 2018). Tending to the voices and experiences of female migrants, another set of studies has examined this group's criminalization at the intersection of migrant condition and gender (Coşkun, 2018), and/or stigmatization based on their choice of employment, specifically focusing on sex workers (Agustín, 2006).

Extant scholarship has revealed an intensification of overall migrant criminalization in recent years (Melossi, 2003; Parkin, 2013), with some research identifying how immigrants are constructed as threats and/or "othered" (Bourbeau, 2011; Menjívar \& Abrego, 2012). On this note, studies reveal a link between migrant criminalization and racialization processes (Abrego et al., 2017; Armenta, 2016, 2017; Armenta \& Vega, 2017; Provine \& Doty, 2011; Stang \& Stefoni, 2016). For example, Brown et al. (2018) have examined negative media portrayals of Latino immigrants-vs. African Americans-in the United States. Altogether they find that, far from constituting independent processes, discrimination goes hand in glove with racialization. Likewise, the authors posit that, just as discrimination and criminalization are racialized, they are also gendered. As Korteweg (2017, p. 432) argues, "the resulting racialized gendered population becomes the subject of abjection onto whom generalized social problems are projected."

By contrast, the literature on the criminalization of migration in the Global South is incipient (Barbero, 2019; Freier \& Pérez, 2021; Oliveira Moreira, 2020; Pérez \& Freier, 2021; Stang \& Stefoni, 2016). With the recent unprecedented level of Venezuelan displacement, scholarship has underscored the overall criminalization of Venezuelan migrants in the region (García, 2020; Pineda \& Ávila, 2019). In Peru, research has documented the country's shift in immigration governance-from an open reception of migrants to heightened securitization measures (Aron \& Castillo Jara, 2020; Freier \& Castillo Jara, 2020)-as well as its effect on the criminalization of Venezuelan migrants and refugees (Condori et al., 2020; Freier \& Pérez, 2021; Pecho Gonzáles, 2020; Pérez \& Freier, 2021). Studies have also documented the "othering" of Venezuelan women, specifically at the intersection of gender, socioeconomic level, nationality, and migration status (Fernández, 2020; Pérez \& Freier, 2021; Pérez \& Ugarte, 2021).

\subsection{Coping Through Satire and Intra-Group Boundary-Making}

Scholars have long studied how vulnerable populations use humor as a coping mechanism (Cardeña, 2003; Husband, 1977; Littlewood, 1993). Specific to migrants, 
Van Ramshorst (2017, p. 14) highlights humor as a mechanism "by which migrants negotiated their vulnerability while also providing a shared source of solidarity between and among them." Along these lines, Gosin (2017) and Koskela (2021) have documented migrants' responses to discriminatory situations in the United States and Europe, respectively, where satire is employed as a coping tactic to deflect against unequal positioning (Koskela, 2021, p. 254). More specifically, in her study of Afro-Cubans in the United States, Gosin $(2017$, p. 7) points to strategies, such as humor, anger, and confrontation, which embody a "wry humor that resists racial hierarchies and processes of racialized subject-making." In this case, the satire is directed both at non-Afrodescendant Cubans, as well as at host nationals who confuse some Cubans' "Blackness" with that of other Afrodescendants. Sarcastic humor is thus a manifestation of migrants' resistance and agency. By contrast, in his study of African and Asian immigrants in Europe, Koskela (2021, p. 254) finds that their use of humor in deflecting racism, for example, is less about claiming superiority, and more a "plea for equality." More broadly, as Van Ramshorst (2017, p. 17) has suggested, "humour is, ironically, a serious topic....Joking and laughter are not only political acts but reveal deeper feelings and dispositions about political subjects." In this way, humor and/or satire may be both a shared style of communication among migrants, as well as a defense shield against their detractors.

Intra-group boundary-making constitutes another response by immigrants to marginalization and/or integration processes. In the case of Ecuadorean migrants living in Italy, Boccagni (2014) has termed their intra-group distinctions as "selective disalignment" to describe the way one cadre of migrants sets itself apart from another less desirable national cohort. Focusing on North Africans in France, Schiff (2021) has studied the relationship between new and "established" migrants, examining how each group uses discourses about itself in its positioning both in French society and among their first- or second-generation compatriots. Similarly, Fathi's (2014) research on female Iranian medical doctors and dentists in Britain depicts how migrants position themselves against their peers in the host country. Finally, the work of Alba et al. (2014) on Mexican migrants in the United States reveals that specific markers, like higher education, intermarriage, and geographic mobility, create intra-group distancing among Mexican-Americans.

Specific to research in the Global South, Stang and Stefoni's (2016, p. 58) study on migration between Colombia and Chile also finds micro-boundary-creation practices among migrants, where class origin plays a key role, and social organization distinguishes against those who are "bad" or delinquent, pitting white and middle-class Colombians, for example, against those of color. In Peru, Loayza (2020) has documented intragroup segregation within the Venezuelan population, with some Venezuelans in Lima engaging in public demonstrations, holding banners that apologize for their compatriots' poor behavior, and others settling in cities with fewer Venezuelans, thus curtailing negative comparisons.

In summary, the research thus far on both migrant criminalization and intra-group boundary-making has more narrowly focused on south-north and east-west experiences. The Venezuelan displacement phenomenon in the region offers a vital opportunity to examine both of these dynamics in a south-south migration context.

\section{Overview}

Although previous emigration waves occurred under former Venezuelan President Hugo Chavez, the economic, political, and humanitarian crisis in Venezuela worsened after his death, as well as with Nicolás Maduro's ascension as president. Along with the drop in oil prices between 2013 and 2016, economic mismanagement caused "chronic shortages of food, medicine, and other basic necessities" (Van Praag, 2019), and violence and organized crime increased (Freier \& Parent, 2019). As the aforementioned situation worsened, Venezuelans increasingly migrated to survive (Paez \& Vivas, 2017), mostly seeking out work and a steady income for themselves to send remittances to family members back home (Caritas, 2018). In this context, Colombia and Peru became the top two destinations in Latin America for Venezuelan migration. Currently ranked as the country with the second-largest share of displaced Venezuelans in the region, Peru has received more than 1.2 million migrants as of October 2021 (R4V, 2021).

Aron and Castillo Jara (2020), as well as Freier and Castillo Jara (2020), have both documented two distinct phases in Peru's policy and political reactions to Venezuelan displacement. In the first one, the government and the overall population adopted a welcoming stance. Many middle- and upper-class Peruvians had a long-standing relationship with Venezuela as a safe haven during the country's internal armed conflict with the Shining Path terrorist group in the 1980s. Overall, under the short-lived Pedro Pablo Kuczynski administration (2016-2018) and through the beginning of Martín Vizcarra's assumption of presidential duties (2018-2020), Venezuelans were welcomed by both free-market-oriented governments with no love lost for Maduro's revolutionary socialist and authoritarian regime (for a brief review of Peru's tumultuous past five years see Castedo, 2020; Vergara, 2020).

By 2019, as Peru's sociopolitical crisis spiked in the aftermath of corruption scandals, ongoing political gridlocks between Vizcarra and the legislative branch, as well as inter-party conflicts, the rate of Venezuelan migration to the country remained unabated. In this highly-charged context, media outlets engaged in increasingly sensationalist reporting on Venezuelan-perpetrated crimes (Freier et al., 2021a). Not limited to newspapers, television programs and social media outlets also contributed 
to the criminalization of Venezuelan immigrants and the dissemination of fake news (Freier et al., 2021a). The effect on public opinion was stark. Indeed, research on Venezuelans in Peru in the past four years has shown that they have been positioned as unworthy, unsavory, and/or criminal, deeply affecting their integration experiences (Freier \& Pérez, 2021; Pérez \& Freier, 2021).

Parallel to criminalization processes by the media and public, the government shifted its earlier welcoming stance to implementing increasingly restrictive entry requirements by mid-2019 (Freier \& Castillo Jara, 2020). By early March 2020, a global pandemic was declared and the Peruvian government's hardened position, relative to the presence of its northwestern neighbors, was highly visible. While the Vizcarra administration doled out small-scale bonuses to Peruvian nationals, Venezuelan residents did not have access to such help, or to government-issued humanitarian aid (Freier et al., 2020). Although it seems that the criminalizing narratives in the media lost prominence vis-á-vis reporting on Covid-19 (Freier et al., 2021a), the repercussions of this criminalization on public opinion continued to be serious. In early 2021, a representative survey found that most Peruvians believed that about half of all Venezuelans were criminals (Freier et al., 2021b). The available statistics, however, suggest that Venezuelans commit significantly fewer crimes than Peruvian nationals, with less than $0.1 \%$ of the Venezuelan population incarcerated in early 2021 (Freier \& Rosales Krumdieck, 2021).

\section{Methods}

Between 2018 and 2020, we collected both quantitative and qualitative data via a survey $(\mathrm{N}=100)$, as well as 72 in-depth, semi-structured interviews and five focus groups, which took place in five Peruvian cities with the largest concentrations of Venezuelan migrants: Arequipa, Cusco, Lima, Tacna, and Trujillo. To recruit the study's participants, we employed snowball sampling, utilizing our contacts with international aid organizations, NGOs, and other personal relationships.

Surveys were administered using a tablet, and applied to both Venezuelan men and women, with primary questions centered on basic demographic data, family work history, experiences with discrimination, and mental health. Survey results for both men and women were later tabulated using the STATA statistical software.

Interviews were conducted exclusively with women, as part of the broader study sought to focus on their particular experiences with socio-labor integration. Interview questions focused on the migration journey, as well as on overall integration experiences. On average, taped interviews lasted 1.5 hours. To contrast our interview data with women, we also conducted five focus groups (one in each city) with men, including questions similarly focused on socio-labor integration experiences. Averaging 10 men each, focus groups lasted approximately two hours. Two facilitators were present-one to lead the discussion and the other to observe and take notes (also documenting verbal and non-verbal reactions). As with the interviews, focus groups were taped, transcribed, and analyzed along the themes/domains noted.

Approved by the Universidad del Pacífico's ethical review board, interview and focus group participants provided their informed consent before data collection. Finally, to protect our participants' privacy, we refer here to subjects as either male or female and share the city where we met.

\section{Results}

In this section, we share relevant descriptive data collected from our survey, interviews, and focus groups.

\subsection{Survey Results}

Applied to 42 men and 58 women, our survey revealed descriptive data about our cohort, as well as information about their experiences with differentiated discrimination, including markers of anxiety and depression among those surveyed. Venezuelans included in this study arrived in Peru between 2017 and 2019, with the majority (78\%) doing so in 2018. Participants' age ranged between 19 and 64, with an average age of 37. More than half of the sample was married (64\%) and $30 \%$ were single. These characteristics are consistent with the data collected during the same period by the International Organization for Migration's (IOM) displacement tracking matrix (IOM, 2020). However, recent studies show that Venezuelans entering Peru are now younger, ranging in age from 18 to 35 (IOM, 2021). Moreover, our sample shows that $78 \%$ have at least one child and $81 \%$ have at least one child in Peru.

Our cohort is highly educated, with $65 \%$ either having been enrolled in a university or having completed a university degree, and $15 \%$ having finished technical education at the time of our encounter. The aforementioned characteristics are consistent with previous studies (INEI, 2019a). Prior to migrating, participants were employed in sales, health, and the education sector. Comparatively, in Peru, participants are mainly employed in the services and sales sectors, mostly working informally (Sánchez et al., 2020).

We also found that Venezuelans experienced varying degrees of discrimination and exploitation in their socio-labor integration process in Peru. Indeed, 71\% of our cohort reported nationality-based discrimination. As shown by Freier and Pérez (2021, p. 120), the experience of discrimination also varied according to participants' age. Relatedly, our survey showed that younger participants, specifically those under 35 years of age, were more exposed to discrimination in comparison to their older counterparts (78 vs. $63 \%$ respectively).

Discrimination, while a key experience for both genders, is a gendered experience: More women (77\%) 
reported being discriminated against in comparison to men (61\%). Additionally, gender-based discrimination was mentioned by $16 \%$ of women (Table 1 ). Women's discrimination is expressed as hyper-sexualization and sexual harassment (Freier \& Pérez, 2021; Pérez \& Ugarte, 2021). Moreover, women are also discriminated against in relation to their age (Pérez \& Freier, 2021).

Finally, our data show that both men and women have experienced anxiety and depression throughout their integration in Peru, although the markers are higher for women regarding depression (Bird et al., 2020).

In summary, Venezuelans in Peru constitute a highly educated, yet vulnerable group. As "migrants of despair," their socio-labor integration experiences are deeply shaped by the country's high levels of informality (70\% to be exact; see INEI, 2019a; Koechlin et al., 2019), social inequality, and discrimination based on ethnicity, geography, and gender markers (Beltrán et al., 2021; Díaz et al., 2021; Galarza, 2012; INEI, 2019b; Manky, 2021).

\subsection{Interviews and Focus Groups}

Freier and Pérez (2021) show how immigrants' discrimination experiences vary depending on whether it occurs in public spaces or the workplace. We found that Venezuelan men and women experience discrimination in public spaces and on their jobs, though, for both, instances of discrimination in the workplace are more frequently reported (Table 2 ).

The subject of criminalization arose during the interviews and focus groups as the main aspect of nationalitybased discrimination. According to the qualitative data, $33 \%$ of women and $43 \%$ of men shared experiences of being criminalized for being Venezuelan. Interestingly, most of the participants that shared experiences of dis- crimination and criminalization in the workspace are employed in the service, sales, and health sectors. Table 3 presents the main types of discrimination identified in the interviews and focus groups.

\section{Discussion}

This section responds to the two questions posed at the outset of this article: How do Venezuelan migrants in Peru approach their criminalization? What are the socioeconomic and political conditions that have hastened migrants' responses?

\subsection{Active Opposition to Criminalization}

Venezuelans in Peru have been discriminated against and rejected in different spaces, both in public and in the workplace, and criminalized based on xenophobic characterizations as unsavory, thieves, prostitutes, and/or murderers (Freier \& Pérez, 2021; Pérez \& Freier, 2021). Venezuelans respond to this criminalization in different ways, two of which we discuss here. First, they may choose to disregard and simply not engage with the discrimination in their daily lives, actively focusing on work and getting ahead. Second, we find specific instances whereby immigrants employ satirical and ironical postures. An overriding attitude is that Peruvians reject them out of their own ignorance. We argue that both the mindful decision to flout the rejections, as well as the use of humor as a shield, serve as coping tools.

\subsubsection{No Time to Engage}

During the focus group session in Lima and chiming in on the discussion of how different compatriots experience,

Table 1. Type of discrimination experienced by gender (quantitative data).

\begin{tabular}{lccr}
\hline & Nationality-based Xenophobia & Discrimination by gender & Discrimination by age \\
\hline Women & $77 \%$ & $16 \%$ & $4 \%$ \\
Men & $61 \%$ & $2 \%$ & $0 \%$ \\
\hline
\end{tabular}

Source: Freier and Pérez (2021).

Table 2. Spaces of discrimination by gender (qualitative data).

\begin{tabular}{lccr}
\hline & Workplace & Public spaces & Other \\
\hline Women & $57 \%$ & $33 \%$ & $10 \%$ \\
Men & $60 \%$ & $31 \%$ & $9 \%$ \\
\hline
\end{tabular}

Source: Freier and Pérez (2021).

Table 3. Type of discrimination by gender (qualitative data).

\begin{tabular}{lcccrr}
\hline & By nationality & Criminalization & By race & By gender & Sexualization \\
\hline Women (interviews) & $85 \%$ & $33 \%$ & $3 \%$ & $39 \%$ & $32 \%$ \\
Men (focus groups) & $60 \%$ & $43 \%$ & $9 \%$ & $0 \%$ & $0 \%$ \\
\hline
\end{tabular}


and make sense of, discrimination, one man mentioned: "We arrive here to get ahead; we don't come to stagnate, to say Peruvians do such and such to me." His advice to the other men-his particular approach to moving forward-was to remember that the only reason for being in Peru was to seek work and a steady income for themselves and their family members back home.

Likewise, one woman interviewed in Lima made the following comment:

If they knew that, while they are saying "if she does this, or doesn't do it," I occupy my mind in my free time...if they could understand that I don't care.... I only care about doing my work and that I have not come here to take away anyone's work.... d don't have the time, truthfully, to think about that.

Finally, and in direct response to instances of gendered discrimination, another woman interviewed in Lima shared her posture relative to the hyper-sexualization and criminalization of her female compatriots:

I stay silent. [They say] that Venezuelans take away husbands, that Venezuelans are prostitutes, that Venezuelans come to sell their bodies. I am Venezuelan, but I have neither prostituted myself nor have I come to sell my body. So, why am I going to defend myself? Why am I going to defend someone that, first, I do not know, and, second, I do not know the situation they are going through? It may...be [true] that their husbands left them for Venezuelans. So, I'd rather keep quiet. I think I get further [ahead] by staying quiet than by engaging in a situation that doesn't make any sense in the long run....Spoiling your day, it's not worth it.

In the three cases shared, we find that Venezuelan men and women's decision to disregard discriminatory and criminalizing remarks constitutes a vital coping mechanism, as their main objective-as "migrants of despair" is to work and get ahead. The first and second comments emphasize the unwillingness to entertain such denunciations; one must focus on surviving and sending remittances back home. The third comment, in response to the devaluation and criminalization of Venezuelan women, steers clear of the accusation, disengaging and proceeding unobtrusively.

\subsubsection{The Joke's on You!}

Conversations with Venezuelans also provide evidence of how they ridicule their detractors, particularly through satirical and ironical postures, in a context in which the political tide has turned against them.

During the focus group session in Tacna, we discussed a gruesome murder that was highly sensationalized in the Peruvian press, whereby a Venezuelan and two Peruvians quartered their victims. To illustrate how such incidents are hyperbolized, one of the focus group participants shared an anecdote about a conversation on the matter with his landlord and the latter's exchanges with other Venezuelan tenants. In his account, the landlord accused Venezuelans of being "vicious murderers." Our focus group participant shared how another Venezuelan tenant brought up-as in rebuttal to the landlord's accusation-that a Peruvian man had recently murdered his wife, chopped up her corpse, and ate it. The landlord relativized the national example, saying it was an unimportant aberration, unrepresentative of Peruvians. Commenting on his response to the landlord's position, the focus group participant shared the following dialogue:

But Mr. Claudio [the landlord]-How can you talk like that, Mr. Claudio? You know, it's still death, we are talking about killing people.... How can you be so cold-blooded to kill, cut her up, cut-to cut, you grab a steak...you eat it. [The landlord replies:] No...but those are crazy people from Puno, the jungle, those crazy people. But you...you come from far away to kill people here [the group laughs]. Then I said, "Mr. Claudio, good night." My wife wanted to get into it with him and I said, "let's go because these people....What can one discuss here? One cannot discuss."

In the focus group session in Cusco, a slender male beautician also referred to the quartering incident and provided an even more directly satirical response to his criminalization. He said:

Look, not long ago, I had an experience....I had another place....and the landlady threw me out because, she said, "you know what? You are a descuartizador [ripper]" What?? Look at me!! [The group laughs] Look at me, look at how they mock, they see me as a faggot, whatever, but a descuartizador...me?? Please!!

The above-noted interactions reveal a few points about the use of satire by displaced Venezuelans. The example used to rebut the landlord's claims of Venezuelan criminality was intended to expose Peruvian ignorance and savagery. The manner in which the participant told the story suggested that he and his compatriots used the barbarous case of the man who ate his wife as a way to scorn their landlord. The explosion of laughter and the ridicule of this scene by the men in the focus group, particularly in response to the landlord's phrase "You...you come from far away to kill people here," which displayed a posture of moral high ground, revealed the irony in the landlord's comments as he could not admit the atrocity of the crime described, and even "otherized" fellow Peruvians. Likewise for the beautician, his self-mockery sought to underscore his landlady's histrionics, thus casting Peruvians as both preposterous and ignorant for 
criminalizing Venezuelans. With these reactions, participants seem to be saying ironically, "the joke's on whom?"

In summary, we find that Venezuelans cope with their criminalization by forging ahead and ignoring the negativity through work and stamina, on the one hand, while also ridiculing and/or satirizing their detractors through humor and/or irony, on the other.

\subsection{Intra-Group Boundary-Making and "Othering"}

Focus groups and interviews also reveal that Venezuelans create boundaries among themselves as a national group. In this section, we address two forms of intragroup distinction. First, interviews revealed how differences are established between "good" immigrants-noncriminal, educated, and worthy-and those who are not. Second, participants' testimonies revealed an expressed fear of the "other."

\subsubsection{Us vs. Them}

Overall, the results from the interviews and focus groups depict how Venezuelans differentiated themselves from their compatriots based on perceptions of criminality, which were assessed regarding linguistic style, educational level, work ethic, and choice of employment. During the focus group session in Cusco, a man poignantly discussed distinction-making practices between those who are considered criminal and those who are not:

I don't know whether it is a cultural question, but we have learned to have intuition-We look at one another, we listen a little to how [they] speak and we say, "this is a tuki [delinquent] or this bug [this thing, this guy] is a choro [delinquent]."

Similarly, one lady interviewed in Trujillo observed:

Unfortunately, there are those compatriots who have come here to commit a crime; they have come to try and sully our true name. We are working people, educated people.

Another woman in Tacna told us:

Yes, it also happens that many young women...like to live the easy life, and then they think that, because one leaves the country, one comes here to do the same. So, it is like they globalize [generalize] everything, all that, and they think that we are all like that.

Interestingly, the three cases shared distinguish between law-abiding, hard-working people and those who fall outside of that particular bracket. In the first comment, the honest Venezuelan is pitted against the criminal counterpart-a distinction that is mostly assessed via people's linguistic style. The second testimony reaffirms the decency of some Venezuelans, as opposed to their delinquent compatriots, via claims centered on education level and work ethic. The last comment makes a criminalizing inference to prostitution-an activity of which Venezuelan women in Peru have been repeatedly accused (Pérez \& Freier, 2021; Pérez \& Ugarte, 2021). As in the other cases, this posture marks the "decent" from the "improper."

Participants also commented on their compatriots' incivility, vulgarity, and/or ignorance, further contributing to their construction as "others." During the focus group session in Tacna, a gentleman observed:

There are people who suddenly come from Venezuela.... d don't know if it's because of their youth...the lack of education, what happened in Venezuela....You see a guy talking and you say, "this guy is lost." How are you going to say here that they [Peruvians] are a cave [pack of] of indios [indigenous people]?

Likewise, in an interview with a woman in Lima, she revealed:

You get on a bus and hear two young Venezuelan women talking and sometimes even I feel embarrassed for them. Because, first, they speak very tough; second, they use dirty language...that the Peruvian is not accustomed to. For example, for us to say arrecho or arrechero means that you're upset. For them [Peruvians], it has a more sexual meaning [horny]. So, then, if you know that the term is offensive, don't say it. Or if you're going to say it, say it more discreetly.

In both cases, we see a class-based distinction in terms of linguistic styles and manners, asserting that some Venezuelans create image problems for those who are trying to integrate successfully. Moreover, we find a vindication of the host society as one that should be respected.

\subsubsection{The Frightening "Other"}

Beyond creating boundaries among compatriots, we have found evidence that intra-group distinctions may be based on different manifestations of fear. For example, in an interview with a woman in Tacna, the participant noted instances of competition and confrontation with other Venezuelans living in Peru:

Even your own people, because sometimes you come to find that your worst enemy here, once you emigrate, is a Venezuelan....There is confrontation when you are selling something: "You cannot share the space with me."

In contrast to the distinctions made among Venezuelans about those who are "good" immigrants, and those who 
are not, the aforementioned quote conveys not only differentiation but a sense of rivalry as well, suggesting a fear of the "other" as an impediment to carving out a proper space to work.

Relatedly, an interviewed woman in Cusco also expressed fear of the political baggage that is brought to Peru by former soldiers and/or government sympathizers on the run from their past deeds. More specifically, she told us:

Some had committed common crimes, homicide, kidnapping, robbery; others had been fleeing...human rights crimes, that is, they had repressed protests, and so on. And they had lost the support of their superiors....So, they are fleeing from Venezuela, from all these crimes that had occurred.

This woman's testimony suggests a fear of political tensions and/or retributions among Venezuelans in a context in which both supporters and dissenters of the Maduro regime have fled the country, and are living among each other in Peru in precarious circumstances.

\subsection{Triggers for Intra-Group Boundary-Making}

As the broader literature on this subject showcases, migrants create intra-group boundaries as the processes and experiences of immigration change over time: the composition of incoming groups becomes more heterogeneous, and second-generation migrants integrate into host societies (Petintseva, 2015; Schiff, 2021). However, our findings suggest that Venezuelan migrants in Peru began to differentiate among themselves around mid-2019. More specifically, boundarymaking practices occurred within the same generation and between migrants who arrived in similar time frames. This also coincided with the Peruvian state's shift toward increased securitization, including, among other things, a cessation of the automatic issuance of temporary resident status (permiso temporal de permanencia) to Venezuelans in June 2019. Instead, Venezuelans required passports for entry into the country. Obtaining the latter was nearly impossible to achieve, considering the state of Venezuela's bureaucracy, as well as the requisite time and resources that obtaining a valid passport would imply. Thus, we found a growing group of migrants with irregular migratory status and who have become more vulnerable (poorer, less educated) over time (Freier et al., 2019). In addition, during this period, media sensationalism flourished in Peru, with statements from public officials, including then-President Martin Vizcarra, which helped to create a spectacle of Venezuelan criminality (Freier \& Castillo Jara, 2020).

This public and media sensationalism around Venezuelan criminality has occurred against the backdrop of a $70 \%$ labor informality rate-one of the highest in the region-as well as poor access to, and quality of, public services (Beltrán et al., 2021; Cueto, 2021;
Guadalupe, 2021; Yamada \& Montero, 2020). As we have noted, Venezuelans have largely flowed to work in the informal sector in a context in which they compete for work with both Peruvians and fellow compatriots. On the one hand, they might satirize Peruvians who discriminate against them, while distinguishing themselves from their compatriots who represent economic competition and/or who may further erode their already precarious positions, on the other.

In her description of newly heightened experiences of discrimination and competition for jobs, one woman interviewed in Cusco commented:

Since when I arrived [it is]...the first time...that I have been unemployed for so long...not even when I first arrived. Because when I first arrived...it was not difficult for me to get a job, even up to three jobs! Imagine! I had two jobs..... Not right now...and I feel that it is for the same...thing...because...in every country there are bad people...so I feel [about the things other Venezuelans have done in Lima], the bad things...that kind of spreads, you know?

Another woman interviewed in Lima expressed her fear about Venezuelans' socioeconomic and political vulnerability. Here, she underscored her active opposition to being criminalized and differentiated herself from other Venezuelans:

I avoid....being in groups where many Venezuelans are acting up.... Here, for example, you cannot afford an illness, right? Ok, if you got sick, fine, but you can't go around looking to get attacked on the street for something silly, for something you could have avoided. Here, if you get sick, they throw you out and you lose your job. So you can't afford a lot of things. So, it's better...to stay out of a lot of situations.

By mid-2019, Peru experienced its own political crisis due to corruption scandals and persistent inequality, which led to the country's about-face on work permit policies and increasing media sensationalism surrounding Venezuelan displacement. As a result, the country's initial welcoming stance toward Venezuelan migrants shifted to increased securitization measures, which, as the prior pages suggest, intensified this group's marginalization and scapegoating. This context may explain why Venezuelans who arrived before the aforementioned policy change used satire and intra-group boundary-making as coping mechanisms to counter their criminalization, specifically differentiating themselves from later-arriving compatriots.

\section{Conclusion}

In the context of Venezuela's economic, humanitarian, and political crisis, and complicated by Peru's sociopolitical insecurity, securitization policies, growing migrant 
vulnerability, and documented criminalization (Freier \& Pérez, 2021; Pérez \& Freier, 2021), we find that Venezuelans confront this situation using both satire and intra-group boundary-making. Overall, we have argued that displaced Venezuelans' use of these coping mechanisms has intensified alongside increasing criminalization in the media and socio-political discourses, as well as more precarious levels of socio-economic integration. In this regard, we have documented how Venezuelans underscore their value while differentiating themselves from later-arriving compatriots.

This case study contributes to the literature on migrants' responses to criminalization and intra-group relations in the Global South, which constitutes an understudied phenomenon. The information gathered on specific coping mechanisms, as well as on the sociopolitical context that has hastened these responses, may inform social policy interventions that seek to address xenophobia while exposing the state's generalized negligence on social protections. At the same time, our research raises questions about the complexity and ramifications of existing social-racial hierarchies in the host country, as well as of migrants' own race and class conceptualizations, in a context of south-south migration. Looking ahead, future research on south-south migration might consider how immigrants' integration and/or adaptation strategies serve to change, maintain or enhance host societies' existing social inequalities.

\section{Acknowledgments}

The research presented here is part of the broader study "Obstacles to the Socio-labor Integration of Venezuelan Migrants in Peru and Implications for National Migration Policy" (\#3010101019), which was awarded research funds in 2018 by the Universidad del Pacífico's Office of the Vice President for Research. This entity, which also serves as the university's ethical review board and is governed by the Code of Ethics for Research and Consulting 2017, approved our research with human subjects. We are thankful for this support as well as for the research and editing assistance of Nícola Espinosa and Andrea Kvietok.

\section{References}

Abrego, L., Coleman, M., Martínez, D. E., Menjívar, C., \& Slack, J. (2017). Making immigrants into criminals: Legal processes of criminalization in the post-IIRIRA era. Journal on Migration and Human Security, 5(3), 694-715. https://doi.org/10.1177/ 233150241700500308

Agustín, L. (2006). The disappearing of a migration category: Migrants who sell sex. Journal of Ethnic and Migration Studies, 32(1), 29-47. https://doi.org/ $10.1080 / 13691830500335325$

Alba, R., Jiménez, T., \& Marrow, H. (2014). Mexican Americans as a paradigm for contemporary intra-group heterogeneity. Ethnic and Racial Studies, 37(3), 446-466. https://doi.org/10.1080/01419870. 2013.786111

Aliaga, F., Flórez, A., García, N., \& Díaz, F. (2020). La integración de los venezolanos en Colombia: Discurso de líderes inmigrantes en Bogotá y Cúcuta [The integration of Venezuelans in Colombia: Discourses from immigrant leaders in Bogota and Cucuta]. Sociología. Problemas e Práticas, 94(1), 39-59.

Armenta, A. (2016). Between public service and social control: Policing dilemmas in the era of immigration enforcement. Social Problems, 63(1), 111-126.

Armenta, A. (2017). Racializing crimmigration: Structural racism, colorblindness, and the institutional production of immigrant criminality. Sociology of Race and Ethnicity, 3(1), 82-95. https://doi.org/10.1177/ 2332649216648714

Armenta, A., \& Vega, I. I. (2017). Latinos and the crimmigration system. In M. Deflem (Ed.), Race, ethnicity and law (Vol. 22, pp. 221-236). Emerald Publishing. https://doi.org/10.1108/S1521-6136201700000 22017

Aron, V., \& Castillo Jara, S. (2020). Reacting to change within change: Adaptive leadership and the Peruvian response to Venezuelan immigration. International Migration. Advance online publication. https://doi. org/10.1111/imig.12761

Barbero, M. V. (2019). Etiquetados: Migrant youth, criminalization, and everyday mobility in Buenos Aires. Ethnic and Racial Studies, 43(9), 1618-1635. https:// doi.org/10.1080/01419870.2019.1649443

Beltrán, A., Cruz Saco, M. A., \& Pérez, L. (2021). Hacia la equidad económica de género entre las adultas peruanas [Toward economic equity among Peruvian women]. In A. Beltrán, C. Sanborn, \& G. Yamada (Eds.), En búsqueda de un desarrollo integral: 20 ensayos en torno al Perú del bicentenario [In search of a comprehensive development: 20 essays on Peru in its bicentennial] (pp. 441-482). Universidad del Pacífico.

Bird, M., Freier, L. F., Luzes, M., Bolívar, L., \& Carroll, H. (2020). Propuesta de política pública no 4: Migración venezolana y salud mental [Public policy proposal no. 4: Venezuelan migration and mental health]. CIUP. https://ciup.up.edu.pe/ppp/haciaintervenciones-para-migrantes-comunidadesacogida

Blouin, C. (Ed.). (2019). Después de la llegada: Realidades de la migración venezolana [After the arrival: Realities about the Venezuelan migration]. IDEHPUCP.

Boccagni, B. (2014). "I'm not like all these Ecuadorians": Promises and dilemmas of immigrants' selective ethnicity appropriation. Social Identities, 20(1), 57-73. https://doi.org/10.1080/13504630.2013.864466

Bourbeau, P. (2011). The securitization of migration: $A$ study of movement and order. Routledge.

Brown, H. E., Jones, J. E., \& Becker, A. (2018). The racialization of Latino immigrants in new destinations: 
Criminality, ascription, and countermobilization. The Russell Sage Foundation Journal of the Social Sciences, 4(5), 118-140. https://doi.org/10.7758/RSF. 2018.4.5.06

Cardeña, I. (2003). On humour and pathology: The role of paradox and absurdity for ideological survival. Anthropology \& Medicine, 10(1), 115-142. https:// doi.org/10.1080/13648470301267

Caritas. (2018). La situación humanitaria en Venezuela vista desde Caritas de Venezuela [The humanitarian situation in Venezuela as seen by Caritas Venezuela]. http://scm.oas.org/pdfs/2018/CP39069TCARITAS VENEZUELA.pdf

Castedo, A. (2020). Martín Vizcarra: Qué es el “Club de la construcción," el escándalo de presunta corrupción que le costó la presidencia al exmandatario peruano [Martin Vizcarra: What is the "Construction club," the alleged corruption scandal that cost the former Peruvian president the presidency]. $B B C$ News. https://www.bbc.com/mundo/noticiasamerica-latina-54896219

Concha, S. (2018). Propuestas para regular las migraciones en Chile y la obstinación del securitismo [Proposals to regulate migrations in Chile and the obstinacy of securitization. URVIO Revista Latinoamericana de Estudios de Seguridad, 23(1), 110-126.

Condori, M., Reyna, G., Villavicencio, A., Párraga, C., \& Vilcapoma, D. (2020). Éxodo venezolano, inserción laboral y discriminación social en la ciudad de Huancayo, Perú [Venezuelan exodus, labor insertion and social discrimination in the city of Huancayo, Peru]. Revista Espacios, 41(27), 72-83.

Coşkun, E. (2018). Criminalisation and prostitution of migrant women in Turkey: A case study of Ugandan women. Women's Studies International Forum, 68(1), 85-93. https://doi.org/10.1016/j.wsif.2018.03.002

Cueto, S. (2021). Las políticas y programas que no se diseñan explícitamente para promover equidad aumentan la inequidad. Una hipótesis para el Perú [Policies and programs that are not explicitly designed to promote equity increase inequity: A hypothesis for Peru]. In C. Guadalupe (Ed.), La educación peruana más allá del Bicentenario: Nuevos rumbos [Peruvian education beyond the bicentennial: New directions]. Universidad del Pacífico.

Díaz, H., Guadalupe, C., \& Yamada, G. (2021). Educación peruana: Avances, nudos y perspectivas [Peruvian education: Progress, knots and perspectives]. CIUP. https://agendabicentenario.pe/ wp-content/uploads/2020/12/Diaz-GuadalupeYamada-Bicentenario-VF.pdf

Escobar, M. (2016). Captivity beyond prisons: Criminalization experiences of Latina (im)Migrants. University of Texas Press.

Fathi, M. (2014). Translocational belonging: Iranian women's narratives of class in Britain. In M. Pajnik \& F. Anthias (Eds.), Work and the challenges of belonging: Migrants in globalizing economies (pp. 93-111).
Cambridge Scholar Publishing.

Fernández, N. (2020). Percepciones mutuas entre venezolanos y peruanos: Raíces de un conflicto [Mutual perceptions between Venezuelans and Peruvians: Roots of a conflict]. Manuscript submitted for publication.

Freier, L. F., Bird, M., Brauckmeyer, G., Kvietok, A., Licheri, D., Luna Román, E., Olivas Osuna, J. J., \& Ponce, P. (2021a). Diagnóstico de la cobertura mediática de la situación de personas refugiadas y migrantes [Diagnosis of media coverage of the situation of refugees and migrants]. ACNUR, Universidad del Pacífico. https://www.acnur.org/sol/sol_int/ 60b84fe84/diagnostico-de-la-cobertura-mediaticade-la-situacion-de-personas-refugiadas.html

Freier, L. F., Bird, M., Brauckmeyer, G., Kvietok, A., Licheri, D., Luna Román, E., Olivas Osuna, J. J., \& Ponce, P. (2021b). Estudio de opinión sobre la población extranjera en el Perú [Opinion study on the foreign population in Peru]. ACNUR, Universidad del Pacífico. https://www.acnur.org/sol/sol_int/ 60b8502f4/estudio-de-opinion-sobre-la-poblacionextranjera-en-el-peru.html

Freier, L. F., \& Castillo Jara, S. (2020). El presidencialismo y la política migratoria en América Latina: Un análisis de las reacciones políticas frente al desplazamiento de ciudadanos venezolanos [Presidentialism and migration policy in Latin America: An analysis of political reactions to the displacement of Venezuelan citizens]. Internacia, 1(1), 1-27.

Freier, L. F., Luzes, M., \& Bolivar, L. (2019). Propuesta de política pública no2: Los impactos adversos de las visas humanitarias [Public policy proposal no. 2: The adverse effects of humanitarian visas]. Ciup. https:// ciup.up.edu.pe/media/1583/ciup-ppp-no2.pdf

Freier, L. F., Luzes, M., \& Castillo Jara, S. (2020). Migración, desigualdad y pobreza en contexto de Covid-19 [Migration, inequality and poverty in the context of Covid-19]. CIUP. https://ciup.up.edu. pe/analisis/migracion-desigualdad-y-pobreza-encontexto-de-covid-19

Freier, L. F., \& Parent, N. (2019). The regional response to the Venezuelan exodus. Current History, 118(805), 56-61.

Freier, L. F., \& Pérez, L. M. (2021). Nationality-based criminalisation of south-south migration: The experience of Venezuelan forced migrants in Peru. European Journal on Criminal Policy and Research, 27(1), 113-133. https://doi.org/10.1007/s10610020-09475-y

Freier, L. F., \& Rosales Krumdieck, O. (2021). Propuesta de política pública no 19: Mitos sobre la criminalidad y la inmigración venezolana al Perú [Public policy proposal no. 19: Myths about criminality and Venezuelan immigration to Peru]. CIUP. https://ciup.up.edu. pe/media/2542/ciup-ppp19.pdf

Galarza, F. (Ed.). (2012). Discriminación en el Perú: Exploraciones en el Estado, la empresa y el mercado laboral [Discrimination in Peru: Exploring the state, the 
firm and the labor market]. Universidad del Pacífico. García, G. (2020, March 20). Venezolanos en Ecuador: Prácticas de seguridad, criminalización y control [Venezuelans in Ecuador: Security criminalization and control practices]. Border Criminologies. https:// www.law.ox.ac.uk/research-subject-groups/centrecriminology/centreborder-criminologies/blog/2020/ 03/venezolanos-en-0

Gosin, M. (2017). A bitter diversion: Afro-Cuban immigrants, race, and everyday-life resistance. Latin Studies, 15(1), 4-28. https://doi.org/10.1057/s41276017-0046-2

Guadalupe, C. (Ed.). (2021). La educación peruana más allá del Bicentenario: Nuevos rumbos [Peruvian education beyond the Bicentennial: New directions]. Universidad del Pacífico.

Husband, C. (1977). The mass media and the functions of ethnic humour in a racist society. In T. Chapman \& H. Foot (Eds.), It's a funny thing humour (pp. 267-272). Pergamon Press.

INEI. (2019a). Condiciones de vida de la población venezolana que reside en Perú-ENPOVE 2018 [Survey directed to the Venezuelan population residing in the country-ENPOVE 2018]. https://www.inei. gob.pe/media/MenuRecursivo/publicaciones_ digitales/Est/Lib1666

INEI. (2019b). Brechas de género 2019. Avances hacia la igualdad de mujeres y hombres [Progress toward the equality of women and men]. https://www. inei.gob.pe/media/MenuRecursivo/publicaciones_ digitales/Est/Lib1716/Libro.pdf

International Organization for Migration. (2020). Displacement tracking matrix (DTM) round 7. https:// displacement.iom.int/system/tdf/reports/IOM\%20 DTM_Monitoreo\%20de\%20Flujo\%20de\%20la\%20 Poblacion\%20Venezolana\%20en\%20el\%20Peru_ Round7_Febrero2020.pdf?file=1\&type=node\& id $=7791$

International Organization for Migration. (2021). Displacement tracking matrix (DTM) round 9. https:// displacement.iom.int/system/tdf/reports/OIM_ PERU_INTERAGC_DP2218_DTM\%20FMS\%209\%20 Tumbes_28Mayo2021.pdf?file=1\&type=node $\&$ id $=11616$

Koechlin, J., Solórzano, X., Larco, G., \& FernándezMaldonado, E. (2019). Impacto de la inmigración venezolana en el mercado laboral de tres ciudades: Lima, Arequipa y Piura [The impact of Venezuelan immigration on the labor market of three cities: Lima, Arequipa and Piura]. IOM; OIT; Ministerio de Trabajo y Promoción del empleo; UARM.

Korteweg, A. C. (2017). The failures of "immigrant integration": The gendered racialized production of nonbelonging. Migration Studies, 5(3), 428-444.

Koskela, K. (2021). Claims to a nation, dressing the part and other boundary making strategies by skilled migrants in response to ethnic categorization. Social Identities, 27(2), 245-261. https://doi.org/10.1080/

\subsubsection{2}

Littlewood, R. (1993). Pathology and identity: The work of mother earth in Trinidad. Cambridge University Press.

Loayza, J. (2020). Inmigración venezolana y estigmatización laboral en el Perú [Venezuelan immigration and labor stigmatization in Peru]. Investigaciones Sociales, 23(43), 179-192. https://doi.org/10.15381/ is.v23i43.18492

Manky, O. (2021). Rostros del trabajo: Desigualdad, poder e identidad en el Perú contemporáneo [Faces of work: Inequality, power and identitiy in contemporary Peru]. Universidad del Pacífico.

McDowell, M. G., \& Wonders, N. A. (2010). Keeping migrants in their place: Technologies of control and racialized public spaces in Arizona. Social Justice, 36(2), 54-72.

Melossi, D. (2003). "In a peaceful life": Migration and the crime of modernity in Europe/Italy. Punishment \& Society, 5(4), 371-397.

Menjívar, C., \& Abrego, L. J. (2012). Legal violence: Immigration law and the lives of Central American immigrants. American Journal of Sociology, 117(5), 1380-1421. https://doi.org/10.1086/663575

Oliveira Moreira, T. (2020). El regreso de la crimigración y el desvanecimiento del carácter humanista de la Ley de Migración Brasileña [The return of crimmigration and the fading humanistic character of Brazilian migration law]. Latin American Law Review, 2020(5), 97-120. https://revistas.uniandes.edu.co/ doi/pdf/10.29263/lar05.2020.05

Paez, T., \& Vivas, L. (2017). The Venezuelan diaspora: Another impending crisis? Fredom House. https:// www.researchgate.net/publication/317099053_ The_Venezuelan_Diaspora_Another_Impending_ Crisis

Parkin, J. (2013). The criminalisation of migration in Europe. A state-of-the-art of the academic literature and research. CEPS. https://www.ceps.eu/system/ files/Criminalisation\%20of\%20Migration\%20in\% 20Europe\%20J\%20Parkin\%20FIDUCIA\%20final.pdf

Pecho Gonzáles, A. (2020). Migración venezolana: De la política "solidaria" al peligroso camino de la criminalización [Venezuelan migration: From "solidarity" politics to the dangerous path of criminalization]. Ideele Revista, 2020(290). https://revistaideele.com/ ideele/content/migraci\%C3\%B3n-venezolana-de-lapol\%C3\%ADtica-\%E2\%80\%9Csolidaria\%E2\%80\%9Dal-peligroso-camino-de-la-criminalizaci\%C3\%B3n

Pérez, L. M., \& Freier, L. F. (2021). "Of prostitutes and thieves": Hyper-sexualization and criminalization of Venezuelan women in Peru. Manuscript submitted for publication.

Pérez, L. M., \& Ugarte, D. (2021). Venezuelan women in Peru: At the borders of nationality, gender, and survival migration. Journal of International Migration and Human Integration, 22(1), 1313-1327. https:// doi.org/10.1007/s12134-021-00805-5 
Petintseva, O. (2015). Approaching new migration through Elias's "established" and "outsiders" lens. Human Figurations: Long-Term Perspectives on the Human Condition, 4(3). http://hdl.handle.net/2027/ spo.11217607.0004.304

Pineda, E., \& Ávila, K. (2019). Aproximaciones a la migración colombo-venezolana: Desigualdad, prejuicio y vulnerabilidad [Approaches to ColombianVenezuelan migration: Inequality, prejudice and vulnerability]. Clivatge, 7(1), 46-97. https://doi.org/ 10.1344/CLIVATGE2019.7.3

Provine, D. M., \& Doty, R. L. (2011). The criminalization of immigrants as a racial project. Journal of Contemporary Criminal Justice, 27(1), 261-277.

R4V. (2021). Refugiados y migrantes de Venezuela [Venezuelan refugees and migrants]. https:// fronteraysociedad.org/portfolio-item/r4vamerica-latina-y-el-caribe-refugiados-y-migrantesvenezolanos-en-la-region-octubre-2021

Sánchez, J., Blouin, C., Minaya, L. V., \& Benites, A. S. (2020). Las mujeres migrantes y refugiadas venezolanas y su inserción en el mercado laboral peruano: Dificultades, expectativas y potencialidades [Venezuelan migrant and refugee women and their insertion in the Peruvian labor market: Difficulties, expectations and potentialities]. CARE, PUCP.

Schiff, C. (2021). Intra-group boundary-making in online discussions between newcomers and descendants of North African immigrants in France. New Diversities, 23(1), 1-16. https://newdiversities.mmg. mpg.de/wp-content/uploads/2021/06/2021_23-

\section{1_02_Schiff.pdf}

Stang, F., \& Stefoni, C. (2016). La microfísica de las fronteras. Criminalización, racialización y expulsibilidad de los migrantes colombianos en Antofogasta, Chile [The microphysics at borders: Criminalization, racialization and the expulsión of Colombian migrants in Antofogasta, Chile]. Astrolabio, 2016(17), 42-80.

Van Klingeren, M., Boomgaarden, H. G., Vliegenthart, R., \& de Vreese, C. H. (2015). Real world is not enough: The media as an additional source of negative attitudes toward immigration, comparing Denmark and the Netherlands. European Sociological Review, 31(3), 268-283.

Van Praag, O. (2019). Understanding the Venezuelan refugee crisis. Wilson Center. https://www. wilsoncenter.org/article/understanding-thevenezuelan-refugee-crisis

Van Ramshorst, J. P. (2017). Laughing about It: Emotional and affective spaces of humour in the geopolitics of migration. Geopolitics, 24(4), 896-915. https://doi. org/10.1080/14650045.2017.1410795

Vergara, A. (2020, November 12). La democracia peruana agoniza [Peruvian democracy is dying]. The New York Times. https://www.nytimes.com/es/2020/11/ 12/espanol/opinion/peru-vizcarra-vacancia.html

Yamada, G., \& Montero, R. (2020). Corrupción e inequidad en los servicios públicos en el Perú [Corruption and inequity in public services in Peru] (Working Paper 87). Universidad del Pacífico. https://www. cies.org.pe/sites/default/files/files/diagnostico ypropuesta/archivos/dyp-50.pdf

\section{About the Authors}

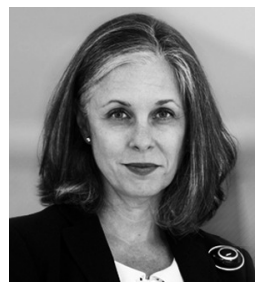

Leda M. Pérez is a social scientist and professor with the Department of Social and Political Sciences at the Universidad del Pacífico (Lima, Peru). Her research explores the intersection of labor and social rights with gender, ethnicity/race, and social class in Latin America. Of particular interest are the care economy and paid domestic workers, migrants, and informal labor regimes. Her research has been published internationally in Gender, Place and Culture, Social Politics, and the Journal of International Migration and Integration, as well as nationally. Prof. Pérez is editor of Apuntes, Revista de ciencias sociales, her University's social science journal. She contributes regularly to El Comercio and La República, Peru's national dailies.

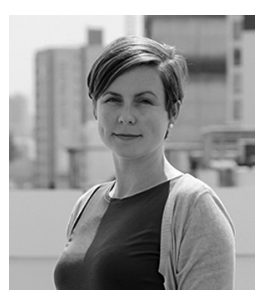

Luisa Feline Freier is a political scientist and professor with the Department of Social and Political Sciences at the Universidad del Pacífico (Lima, Peru). Her research focuses on migration and refugee policies and laws in Latin America, south-south migration, and the Venezuelan displacement crisis. Prof. Freier has published widely in both academic and media outlets and has been interviewed on the Venezuelan displacement crisis in international media, including BBC, El País, La Presse, and The Economist. Prof. Freier has provided advice to various international institutions and organizations such as Amnesty International, IOM, UNHCR, the World Bank, and the EU. She is migration research and publishing high-level adviser of the IOM. 